\title{
Management of Fruit Rot Disease of Arecanut Incited by Phytophthora meadii
}

\author{
H. Narayanaswamy*, J. Raju and K. Jayalakshmi \\ Department of Plant Pathology, ZAHRS, University of Agricultural and Horticultural Sciences, \\ Shivamogga, 577225, Karnataka (India) \\ Department of Plant Pathology, Plant Quarantine Station, DPPQS, Mangalore, Karnataka (India) \\ *Corresponding author email id:
}

\section{A B S T R A C T}

Arecanut is one of the major agriculturally important palm cultivated in humid tropics of India. Phytophthora "the plant destroyer" cause severe devastating diseases in arecanut

\begin{tabular}{|l|}
\hline Ke y w or d s \\
Arecanut, Fruit \\
rot, Phytophthora, \\
Management, \\
Bordeaux mixture. \\
\hline Article Info \\
\hline Accepted: \\
29 June 2017 \\
Available Online: \\
10 July 2017 \\
\hline
\end{tabular}
palms. Fruit rot of arecanut is caused by the fungus Phytophthora spp. causes fresh infection during the monsoon and subsequent cooler months. The fungus survives as oospores, chlamydospores and mycelium in soil, on fallen nuts, on dried nuts and on inflorescence remaining in the crown. During 2014, a bulk farm trail was with Conventional Bordeaux mixture 1\%, Stabilized Blue Bordeaux 1\%, Metalaxyl Mz 0.2\%, Copper Oxychloride 0.3\%, Cymoxanil + Mancozeb @ 0.2\% and potassium phosphonate products (Biofight $0.5 \%$ and Biopot $0.5 \%$ ). The result indicated that the number of fallen nuts due to fruit rot incidence was $33.17 \%$ per palm. Application of conventional Bordeaux mixture at $1 \%$ has significantly reduced number of fallen nuts due to fruit rot of arecanut at 6 locations $(0.91)$ and increased the nut yield (green nut $9230.44 \mathrm{~kg} / \mathrm{acre}$ and dry nut $1200.32 \mathrm{~kg} / \mathrm{acre}$ ) followed by one percent of stabilized Bordeaux mixture and Metalaxyl MZ. Maximum disease incidence and affected fallen nuts was recorded in untreated check.

\section{Introduction}

The arecanut palm (Areca catechu L.) is one of the most important plantation crops in Karnataka. It is commonly known as betelnut or supari and used in various religious and social ceremonies. Although, India is the largest producer of arecanut its productivity is very low, $1214 \mathrm{~kg} / \mathrm{ha}$. Besides, arecanut cultivation is beset with recurring problems due to reduced productivity, delayed commercial yield, soil fertility depletion, small holding size, price fluctuation and pests and diseases. Among the many reported diseases, fruit rot or Mahali (heavy devastation) or Koleroga caused by
Phytophthora meadii is a serious fatal disease causing huge loss to farmers. The disease may cause fruit drop of 50 to 100 per cent in individual palms if timely and proper control measures are not adopted. Fruit rot disease occurs in all the arecanut growing regions receiving heavy rainfall during southwest monsoon period (June- September). Though the disease is sporadic in nature, outbreaks of epidemic are also common during favourable climatic conditions especially in years of prolonged rainy season. Bultler (1906) first recorded the disease in the Karnataka. The disease was reported from the Dakshina 
kannada and Uttara kannda districts of Karnataka as well as in small pockets of Malabar and cochin. The intensity of the disease is increasing year after year due to build up of inoculums in the endemic areas of Karnataka causing severe economic loss. Though the $P$. meadii is the major pathogen causing fruit rot, association of other $P$. palmivora and other species has been reported in rare occasions (Hegde and Chowdappa, 2015). Infection of $P$. meadii produces characteristic symptom like rotting and extensive shedding of the immature nuts which lie scattered near the base of the tree. Hence an attempt was made to use conventional contact fungicides like Bordeaux mixture, copper oxy chloride, kocide, along with judicial use of Metalaxyl MZ, curzate and bio-products like biofight and biopot for the effective management of the disease in arecanut cropping system.

\section{Materials and Methods}

The experiment in randomized block design was laid out in farmer's field in Varadamula, Hosavi, Tuppooru, Kouti, Wodeyala and Bobbi village of Shimoga district of Karnataka during 2014. The arecanut palms were treated alone and in combinations of fungicides viz., Conventional Bordeaux mixture $1 \%$, Stabilized Blue Bordeaux 1\%, Metalaxyl + Mancozeb (Metalaxyl Mz) 0.2\%, Copper oxychloride, 0.3\%, Cymoxanil + Mancozeb @ $0.2 \%$ and potassium phosphonate products (Biofight $0.5 \%$ and Biopot $0.5 \%$ ) along with removal of fallen nuts, provision of drainage, cutting of excessive branches of inter crops like black pepper, cocoa, clove, nutmeg, cardamom, cinnamon and branches of forest trees around arecanut gardens for proper aeration during third week of may month gives the better management of fruit rot. And application of agricultural lime at $200 \mathrm{~kg} /$ acre to neutralize soil before on set of monsoon controls the disease. The treatments were imposed twice in the season i.e., first week of June and second week of August. The arecanut palm without any fungicidal application was served as control. The observation were taken on infected fallen nuts (\%), was recorded during onset of monsoon, peak monsoon and post monsoon and also green nut and dry nut yield were recorded and benefit cost ratio was calculated and collected data was analyzed statistically.

\section{Results and Discussion}

During the year 2014, bulk farm trial was conducted in six locations in moderate to heavy rainfall areas to control fruit rot of arecanut. Data on the incidence as measured by the percentage of infected fallen fruits are presented in table 1. The result indicated that the number of fallen nuts due to fruit rot incidence was ranged from 0.30 to $33.17 /$ palm from all villages.

Application of conventional Bordeaux mixture at $1 \%$ has significantly reduced number of fallen nuts due to koleroga (fruit rot) of arecanut at 6 locations (0.91) followed by stabilized Bordeaux mixture at $1 \%$. Further Metalaxyl MZ treatment was found effective. Maximum disease incidence or affected fallen nuts was recorded in untreated check.

In varadmula village minimum nut drop of $0.63 \%$ was recorded in $1 \%$ conventional Bordeaux mixture sprayed trees followed by stabilized Bordeaux mixture, copper oxychloride and cymoxanil + mancozeb $(1.33,2.10$ and $2.30 \%)$ which were remains on par with each other. The next best treatment was Metalaxyl $\mathrm{Mz}$ which recorded less nut drop of $2.83 \%$. Whereas the maximum nut drop was recorded untreated check (25.63\%). However the potassium phosphonate products viz., Biofight and Biopot found less effective. 
Table.1 Effect of alternate fungicides to Bordeaux mixture against fruit rot disease of Arecanut during kharif 2014

\begin{tabular}{|c|c|c|c|c|c|c|c|c|}
\hline \multirow[t]{2}{*}{ Treatments } & \multicolumn{6}{|c|}{ Avg. no. of fallen nuts/palm (infected) (\%) } & \multirow{2}{*}{$\begin{array}{c}\text { Avg. } \\
\text { Nut } \\
\text { drop } \\
(\%)\end{array}$} & \multirow{2}{*}{$\begin{array}{c}\% \\
\text { decrease } \\
\text { over } \\
\text { control } \\
\end{array}$} \\
\hline & Varadamula & Hosavi & Tuppooru & Kouti & Wodeyala & Bobbi & & \\
\hline $\begin{array}{l}\text { Conventional Bordeaux } \\
\text { mixture @ } 1 \%\end{array}$ & 0.63 & 1.47 & 0.43 & 1.23 & 0.30 & 1.40 & 0.91 & 96.37 \\
\hline $\begin{array}{ll}\text { Stabilized } & \text { Bordeaux } \\
\text { mixture } 1 \% & \end{array}$ & 1.33 & 1.97 & 1.43 & 2.33 & 0.30 & 1.90 & 1.54 & 93.85 \\
\hline Biofight @ 0.5\% & 5.63 & 5.77 & 8.93 & 7.23 & 6.57 & 4.90 & 6.51 & 74.04 \\
\hline $\begin{array}{l}\text { Cymoxanil+mancozeb } \\
\text { @ } 0.2 \%\end{array}$ & 2.30 & 4.30 & 6.65 & 5.13 & 2.23 & 3.70 & 4.05 & 83.85 \\
\hline Suraksha@0.5\% & 4.50 & 8.40 & 7.05 & 6.40 & 5.13 & 6.93 & 6.40 & 74.48 \\
\hline Biopot @ 0.5\% & 6.60 & 9.30 & 7.70 & 7.13 & 6.07 & 7.17 & 7.33 & 70.77 \\
\hline $\begin{array}{l}\text { Copper oxychloride } \\
@ 0.25 \%\end{array}$ & 2.10 & 3.10 & 4.55 & 4.53 & 2.13 & 2.07 & 3.08 & 87.72 \\
\hline Metalaxyl MZ @0.2\% & 2.83 & 2.97 & 4.33 & 1.83 & 2.10 & 3.50 & 2.93 & 88.32 \\
\hline Untreated check & 25.63 & 33.17 & 24.00 & 22.00 & 20.33 & 25.33 & 25.08 & - \\
\hline S.Em \pm & 0.33 & 0.18 & 0.25 & 0.12 & 0.20 & 0.17 & & \\
\hline CD@5\% & 1.26 & 0.76 & 0.84 & 0.89 & 0.79 & 0.67 & & \\
\hline
\end{tabular}

Table.2 Effect of fungicides on yield parameter in fruit rot affected palms (green nut and dry nut yield $\mathrm{kg} / \mathrm{ac}$ )

\begin{tabular}{|l|c|c|}
\hline Treatments & $\begin{array}{c}\text { Green and Dry nut yield } \\
\text { (Kg/ac) }\end{array}$ & $\begin{array}{c}\text { \% increase over } \\
\text { control }\end{array}$ \\
\cline { 2 - 2 } & $\begin{array}{c}\text { Avg. yield of 6 locations } \\
\text { 9230.44* (1200.32)** }\end{array}$ & 145.32 \\
\hline Conventional Bordeaux mixture @ 1\% & $8662.99(1126.53)$ & 130.24 \\
\hline Stabilized Bordeaux mixture 1\% & $6697.70(870.96)$ & 78.01 \\
\hline Biofight @ 0.5\% & $7390.56(961.06)$ & 96.42 \\
\hline Cymoxanil+Mancozeb @ 0.2\% & $6655.21(865.44)$ & 76.88 \\
\hline Suraksha @ 0.5\% & $6440.12(837.47)$ & 71.16 \\
\hline Biopot @ 0.5\% & $7698.20(1001.07)$ & 104.60 \\
\hline Copper oxychloride @0.25\% & $7840.89(1019.62)$ & 108.39 \\
\hline Metalaxyl Mz @0.2\% & $3762.60(489.28)$ & \\
\hline Untreated check & 0.31 & \\
\hline S.Em \pm & 1.18 & \\
\hline CD @ 5\% & & \\
\hline
\end{tabular}

Similarly, in Hosavi, Tuppooru, Kouti, Wodeyala and Bobbi villages also minimum nut drop was recorded in trees which received
$1 \%$ conventional Bordeaux mixture (1.47, $0.43,1.23,0.30$ and $1.40 \%)$ respectively, followed by stabilized Bordeaux mixture, 
copper oxychloride and cymoxanil + mancozeb.

Fruit rot of arecanut being season bound, it is the previous seasons inoculum in the form of latent infection within the dried bunches and canopy which serves as initial inoculums. The secondary spread is by means of sporangia which are produced abundantly on the infected fruits. The minimum incidence of fruit rot in Bordeaux mixture and Metalaxyl MZ treated plots may be due to reduced number of secondary inoculums due to antisporulant activity of this fungicide (Anandraj and Sarswathy, 1986), there by restricting the rapid secondary spread of the disease. For such mode of action the time of application of fungicide is critical. The spraying has to be done soon after the primary inoculums resume its activity and just before secondary spread gathers momentum. Similar findings was obtained by Hegde and Anahosur (1998), the integrated management of foot rot of black pepper where in application of neem cake + Trichoderma harzianum + Metalaxyl $\mathrm{Mz}+$ garlic and mustard seed extract + mulching of the wet soil with transparent polythene sheets during the hot summer was the most effective treatment and resulted in maximum survival of vines. The present findings are in conformity with the work of Ramesh et al., 2014 and Narayanaswamy et al., 2015. Jeeva et al., (2015) also showed that Copper and metalaxyl fungicides are very effective in controlling leaf blight of taro caused by $P$. colocasiae.

Correspondingly, the data presented in the table 2 revealed that application of conventional Bordeaux mixture at $1 \%$ has significantly increased the nut yield (green and dry) at 6 locations over control of 9230.44 and $1200.32 \mathrm{~kg} / \mathrm{ac}$ respectively. Further, stabilized Bordeaux mixture 8662.99 and $1126.53 \mathrm{~kg} / \mathrm{ac})$, Metalaxyl Mz (7840.89 and $1019.62 \mathrm{~kg} / \mathrm{ac})$, copper oxychloride
(7698.20 and $1001.07 \mathrm{~kg} / \mathrm{ac}$ ) and cymoxanil + mancozeb (7390.56 and $961.06 \mathrm{~kg} / \mathrm{ac})$ recorded maximum nut yield, whereas, less nut yield was recorded in untreated check (3762.60 and $489.28 \mathrm{~kg} / \mathrm{ac}$ ) respectively. The results are conformity with the findings of Lokesh et al., (2014) reported that arecanut bunches treated with systemic fungicide Metalaxyl MZ 72 WP @ 2 g/l as spray for twice was effective in reduction of the disease and increase in the yield.

The results of the present finding clearly showed that the disease could be managed by application of either conventional or stabilized Bordeaux mixture (1\%) as foliar spray along with removal of fallen nuts, provision of drainage, cutting of excessive branches of inter crops like black pepper, cocoa, clove, nutmeg, cardamom, cinnamon and branches of forest trees around arecanut gardens for proper aeration during third week of may month gives the better management of fruit rot. And application of agricultural lime at $200 \mathrm{~kg} / \mathrm{acre}$ to neutralize soil before on set of monsoon controls the disease. Over the years various chemicals were screened for the management of the Phytophthora diseases in arecanut. Fungicidal spray could control the disease only to a limited extent as the as the heavy rains resulted in washing off of the fungicides from plant surface. An integrated disease management involving proper cultural practices, application of biocontrol agents, fungicidal sprays and host plant resistance need to be employed for effective management. It is easier said than practice the effective control measures for Phytophthora disease in the perennial trees like arecanut grown in high rainfall areas.

\section{References}

Anandraj, M. and Sarswathy, N. 1986. Effect of systemic fungicides on fruit rot of arecanut. Indian Phytopath., 39: 607- 
610.

Hegde, V. and Chowdappa, P. 2015. Phytophthora diseases of palms. In $3^{\text {rd }}$ International symposium on phytophthora: taxonomy, genomics, pathogenecity, resistance and disease management, 9-12 $2^{\text {th }}$ September., 66p.

Lokesh, M.S., Patil, S.V., Palakshappa, M.G. and Gurumurthy, S.B. 2014. Role of systemic fungicide metalaxyl mancozeb in management of Koleroga (Phytophthora meadii Mc Rae) of arecanut (Areca catechu L.) in Central Western ghats of Karnataka. Asian J. Bio. Sci., 9(1): 131-133.

Narayan Swamy, H., Raju, J., Sharanappa, H.G., Murali R. and Shrinidhibharathisha Navilekar. 2015. Management of fruit rot of arecanut caused by Phytophthora meadii under in vivo conditions. In $3^{\text {rd }}$ International symposium on phytophthora: taxonomy, genomics, pathogenecity, resistance and disease management, IIHR, Banglore, $51 \mathrm{p}$.

Ramesh R., Maruthadurai R. and Singh N.P. 2014, Management of fruit rot (Koleroga/ Mahali) disease of Arecanut Extension Folder No. 67. ICAR Research Complex for Goa, Old Goa.

Jeeva M.L., Veena S.S., Vishnu S. Nath, Senthil Sankar, B. Shyni, and R.S. Misra. 2015. Phytophthora diseases of cassava and taro. In $3^{\text {rd }}$ International symposium on phytophthora: taxonomy, genomics, pathogenecity, resistance and disease management, IIHR, Banglore, 63-65.

\section{How to cite this article:}

Narayanaswamy, H., J. Raju and Jayalakshmi, K. 2017. Management of Fruit Rot Disease of Arecanut Incited by Phytophthora meadii. Int.J.Curr.Microbiol.App.Sci. 6(7): 2824-2828. doi: https://doi.org/10.20546/ijcmas.2017.607.393 